\title{
Brain Death and Deceased Organ Donation in a Hospital in İstanbul, Turkey: The Effect of Early Identification of Brain Dead on Organ Donation Rates: A Retrospective Study
}

\author{
Beyin Ölümü Erken Tanısının Organ Bağıș Oranına Etkisinin Retrospektif Analizi
}

\author{
Tuğçe Yeniocak1, (1) Perihan Ergin Özcan²
}

${ }^{1}$ Metin Sabancı Baltalimanı Bone and Joint Diseases Training and Research Hospital, Clinic of Anesthesiology, İstanbul, Turkey

2istanbul University Faculty of Medicine, Department of Anesthesiology, İstanbul, Turkey

\begin{abstract}
Introduction: The possibility of brain death (BD) among patients with a Glasgow Coma scale $<7$ must be considered by physicians who work in intensive care units. Deceased organ transplantation can be lifesaving so every BD patient should be seen as a potential donor. The aim of this study was to describe the causes of $\mathrm{BD}$, rate of organ donation and to investigate the effect of diagnosis time on donation rates in our hospital over a 9-year period.
\end{abstract}

Methods: After obtaining Institutional Ethics Committee approval, we conducted a retrospective review of patients who had sustained BD in our hospital between January 1, 2004 and January 1, 2013. Patients' age, methods used to diagnose BD, duration of survival after diagnosis, whether patients' family members gave consent to organ donation, and organ donation rates were reviewed.

Results: Sixty patients were declared BD, of whom 21 (35\%) were female and 39 (65\%) were male. Their mean age was 28 years. Only $6(10 \%)$ patients' families gave consent for donation. The most common cause of BD was traumatic brain injury $(n=37,62 \%)$. Internal carotid artery doppler ultrasonography was performed in $36(60 \%)$ patients; cerebral angiography was performed in $14(23 \%)$ patients; and electroencephalography was performed in two patients. The mean time from hospital admission to diagnosis of BD was $5.16 \pm 3.06$ days overall; $5.5 \pm 0.4$ days among non-donors; and $2.0 \pm 0.4$ days among donors. The mean time from diagnosis of BD to death in non-donors was $2.4 \pm 0.3$ days. In donors, the mean time from diagnosis of BD to harvesting of the patient's organs was $1.08 \pm 0.2$ days.

Conclusion: In our hospital, the rate of organ donation after $\mathrm{BD}$ is low. It is found that the time to confirm the diagnosis of $\mathrm{BD}$ was significantly shorter in donors than non-donors. It is believed that early diagnosis of $\mathrm{BD}$ is associated with an increased rate of family approval for organ donation.

Keywords: Brain death, organ donation, deceased organ donation, transplantation

\section{öZ}

Amaç: Yoğun bakımda takip edilen Glasgow Koma skoru 7'nin altındaki hastalarda beyin ölümü gelişme intimaline karşı uyanık olunmalıdır. Kadavradan organ nakli; nakil sırası bekleyen hasta sayııını düşüreceğinden hayat kurtarıcıdır. Bu nedenle her beyin ölümü tanısı konan hastaya potansiyel donör gözüyle bakıımalıdır. Çalışmamızın amacı hastanemizde dokuz yıllık süreçte tanı alan beyin ölümü olgularını inceleyerek beyin ölümü nedenlerini araștırmak, tanı alma sürecindeki testleri ve kadavradan organ nakil oranını incelemektir. İkincil amacımız beyin ölümü tanı konma süresinin bağıs oranına etkisini araştırmaktır.

Yöntemler: Etik Kurul onayı alınarak 1 Ocak 2004 ve 1 Ocak 2013 tarihleri arasında hastanemiz yoğun bakım ünitesinde beyin ölümü tanısı alan hastalar retrospektif olarak incelendi. Hastaların yaşı, beyin ölümü tanısında uygulanan testler, hastaneye gelișten beyin ölümü tanısı alana kadar geçen süre, tanı sonrası hastaların sağkalım süresi, ailelerin organ bağıșına onay verip vermemeleri ve organ nakil oranları incelendi.

Bulgular: Altmış hasta beyin ölümü tanısı aldı, 21'i (\%35) kadın, $39^{\prime} u(\% 65)$ erkekti. Ortalama yaş 28 'di. Sadece 6 (\%10) aile organ bağıșı için onay verdi. Beyin ölümünün en sık nedeni travmatik beyin hasarı (37; \%65) olarak bulundu. Beyin ölümü klinik testlerin yanı sıra $36(\% 60)$ hastaya internal karotis dopler, $14(\% 23)$ hastaya serebral anjiyografi, 2 hastaya da elektroensefalografi yapıllarak tanı konuldu. Hastaneye geliş ile tanı konmasına dek geçen süre ortalama 5,16 $\pm 3,06$ gün; donör grubunda 2,0 $\pm 0,4$ gün, donör olmayan grupta $5,5 \pm 0,4$ gün olarak bulundu. Tanıdan kardiyak ölüme dek geçen süre donör olmayan grupta $2,4 \pm 0,3$ gün olarak bulundu. Tanı konduktan sonra donör grubunda organ nakline kadar geçen süre $1,08 \pm 0,2$ gündü.

Sonuç: Hastanemizde beyin ölümü sonrası organ bağış oranı oldukça düşük bulundu. Potansiyel donörlerin erken fark edilmesi ile organ bağış oranı artışı arasında istatistiksel anlamlı fark tespit edildi. Beyin ölümü tanısının erken konulması organ bağış oranını yükselterek nakil sırası bekleyen hastalar için umut ışı̆ı̆ı olacaktır.

Anahtar Kelimeler: Beyin ölümü, organ nakli, kadavradan organ nakli, transplantasyon 


\section{Introduction}

Brain death (BD) occurs as intracranial pressure increases due to the edema of brain tissue within the rigid borders of the skull. Once intracranial pressure equals or exceeds the systemic arterial pressure, the nutritional blood supply to brain tissue stops. This is followed by a rapid decrease in the intracranial pressure gradient and results as intracranial circulatory arrest. While death is traditionally characterized as cardiac arrest and loss of vital functions, advances in technology have made it possible to prevent somatic death despite an irreversible loss of brain function in the intensive care unit (ICU) setting. In these cases, providing prolonged life support can mislead family members about the severity of the patient's condition and give them false hope that the patient will recover. Also, the practice of providing life support after BD can cause spiritual distress among family members and long-term hospitalization increases the cost of ICU treatment (1).

Worldwide, hundreds of people on waiting lists for organ transplantation die of organ failure. There are currently insufficient organs donated by living donors to meet all of the demand for organ transplants. According to Turkish Ministry of Health figures, 779 people in Turkey died while awaiting organ transplants in 2018. In Turkey, there are currently 26,524 patients registered in organ and tissue information systems on waiting lists for organ transplants. Of these patients, 22,868 patients are on the waiting list for kidney transplant, 1,116 patients are on the list of heart transplant, 2,250 patients are on the list of liver transplant, 82 patients are on the list of lung transplant, 5 patients are on the list of bowel transplant and 289 patients are on the list of pancreas transplant (2).

The primary objective of this study was to analyze the causes of $\mathrm{BD}$, the criteria used for determination of BD, ancillary tests for diagnosing BD, the duration of hospitalization before diagnosis, and the duration of survival after diagnosis. Secondary objective was to determine the rates of family consent for organ donation, and the effect of diagnosis time of $\mathrm{BD}$ in donation rates.

\section{Methods}

After obtaining Institutional Ethics Committee approval by İstanbul University Clinical Research Ethics Council (decision no: 2013/1748), we conducted a retrospective review of 60 patients diagnosed as brain dead in İstanbul Medical Faculty Hospital between January 1, 2004 and January 1, 2013. The hospital's Organ Transplant Coordinator provided data on all patients who had been diagnosed as brain dead while in the ICUs of the Departments of Anesthesiology, Neurosurgery, or Emergency Surgery.

Patients with metabolic endocrine disorders and affected by depressant drugs or neuromuscular block were excluded. Brainstem reflex tests were performed by ICU doctors to all patients who had Glasgow Coma scale $<7$ (Table 1). After declaration of BD, patients' families were informed about the option of deceased organ donation.

We reviewed patients' age at death, main diagnosis, length of stay in ICU, ancillary tests such as internal carotid artery doppler ultrasonography (ICAUSG), cerebral angiography (CA), electroencephalography (EEG), their religion and family consent for organ donation.

\section{Statistical Analysis}

Data were analyzed using Statistical Package for the Social Sciences (SPSS software for Windows, version 22.0 Corp., Amonk, NY, USA). The mean, standard deviation and percentage values were calculated as descriptive statistics. Categorical data were compared using the independent sample t-test. $\mathrm{P}<0.05$ were regarded as statistically significant.

\section{Results}

During the study period, 60 patients were declared as BD, of whom 21 (35\%) were female and 39 (65\%) were male. Their mean age was 28 years. The most common cause of BD was traumatic brain injury $(n=37,62 \%)$. ICAUSG was performed in $36(60 \%)$ patients; CA was performed in 14 (23\%) patients; both ICAUSG and CA were performed in $12(20 \%)$ patients and EEG was performed in 2 (3.33\%) patients. Only $6(10 \%)$ patients' families gave consent to donation. Other patient characteristics are shown in Table 2. The mean time from hospital admission to diagnosis of BD was $5.16 \pm 3.06$ days overall; $5.5 \pm 0.4$ days among non-donor group; and $2.0 \pm 0.4$ days among donor group. It is found that the time to confirm the diagnosis of BD was significantly shorter in donors than in non-donors $(p=0.000)$. The mean time from diagnosis of brain dead to death in non-donor group was $2.4 \pm 0.3$ days. In donor group, the mean time from diagnosis of $\mathrm{BD}$ to harvesting of the patient's organs was $1.08 \pm 0.2$ days. Total hospitalization time in donor group was $3 \pm 0.6$ and in $7.6 \pm 0.4$ in non-donor group. As it is predicted, statically significant difference was found in total hospitalization time. It is related to immediate transplantation after consent in donor group $(p=0.000)$ (Table 3) (Figure 1).

\section{Discussion}

The most common causes of BD among the patients in our study were traumatic intracranial hemorrhage (62\%) and ischemic strokes (20\%). These findings are similar to those of other studies. In a study conducted in Portugal, Eira et al. (3) found that the most common causes of BD were hemorrhagic strokes (55.3\%) and ischemic strokes (17.4\%). In Turkey, in a study by Karasu et al. (4), they found that $73 \%$ of patients who experienced BD in the ICU had been admitted for bleeding-obstructive

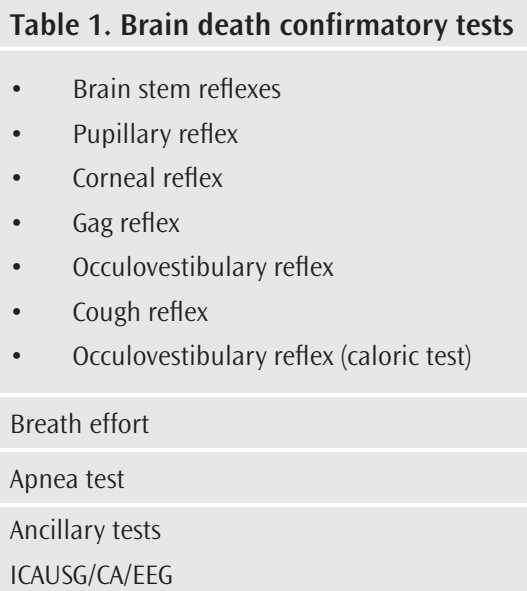

ICAUSG: internal carotid artery doppler ultrasonography, CA: cerebral angiography, EEG: electroencephalography 
Table 2. Demographic characteristics of the patients

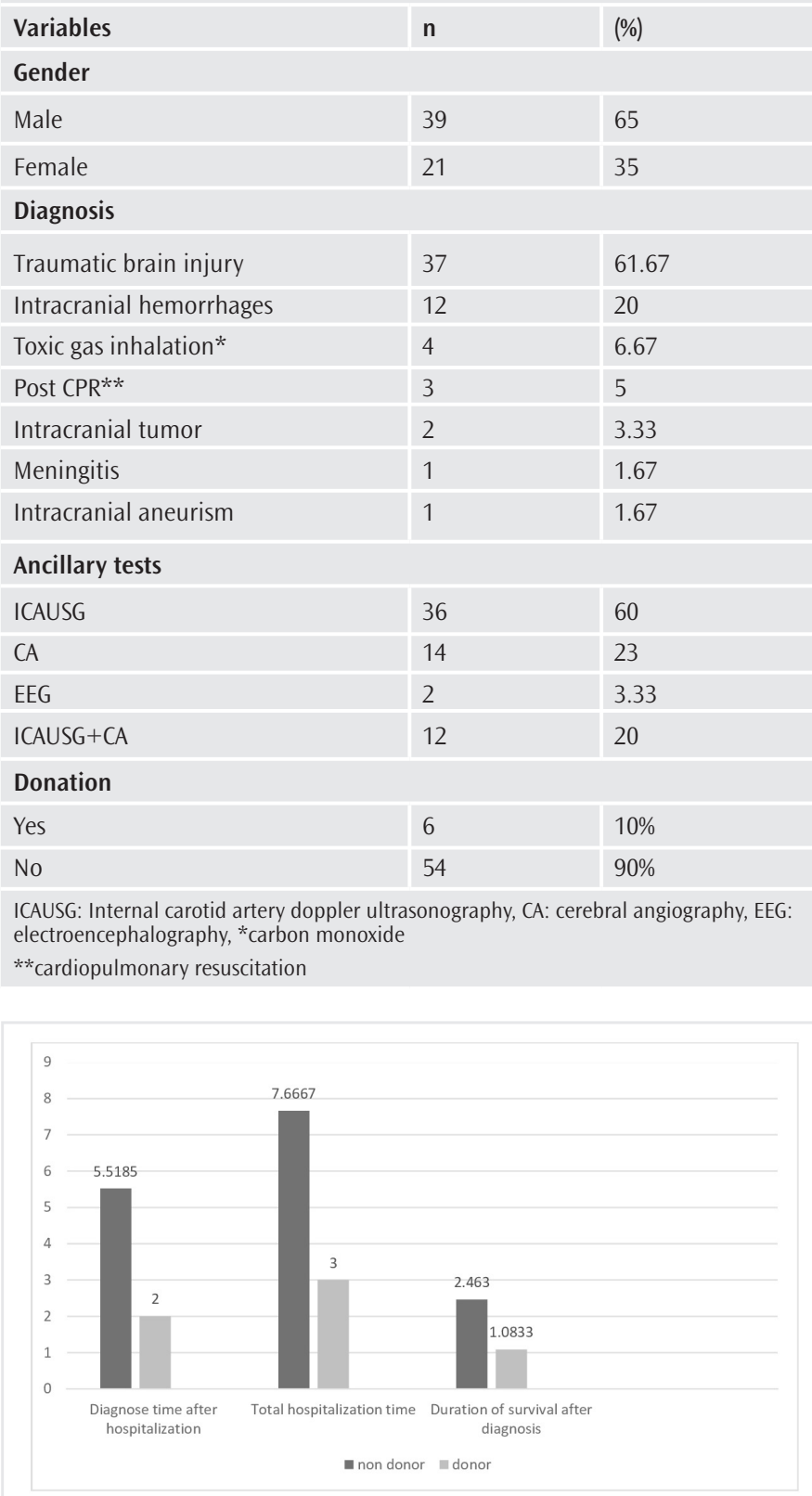

Figure 1. Hospitalization time and diagnosis cerebrovascular disease, and in a study by Battal et al. (5), the most common cause of BD (58\%) was reported to be intracranial hemorrhage.

The use of ancillary tests for diagnosing BD varies according to the experience of the clinicians and the settings. In our study, $83.3 \%$ of the patients had the diagnosis of BD confirmed by radiological examinations of cerebral blood flow, and $16.3 \%$ had BD diagnosed on clinical grounds alone. In the study by Karasu et al. (4), only $30.4 \%$ of the patients had BD confirmed by ancillary tests (13\% ICAUSG and 13\% CA); while in a study by Mutlu et al. (6), 76.2\% of patients had BD confirmed using ancillary tests (22.3\% CA, 13.8\% ICAUSG, and 20\% ICA and ICAUSG combined).

In our study, only $6(10.0 \%)$ of the families gave consent for organ donation. This rate is quite low compared to other countries. Organ donation rates are measured as an organ donation per million population (ppm). Turkey has one of the lowest rates of deceased organ donation of all the countries in Europe with a rate of $2.2 \mathrm{ppm}$, compared to 15-20 ppm in other European countries (7). The rates differ among the hospitals in Turkey. In a 7-year study from Izmir, the families of $34.2 \%$ of patients diagnosed with BD consented to deceased organ donation (8). A study by Özmert et al. (9) in a tertiary pediatric ICU of Ankara Child Health and Diseases Hematology Oncology Training and Research Hospital, they found a donation rate of $17 \%$ among children in a pediatric ICU. Another study found an organ donation rate of $23.8 \%$ in Ankara Numune Training and Research Hospital (6).

In Europe, a whole 80\% of all organ donations are from deceased donors. Conversely, in Turkey, $75 \%$ of organ donations are from living donors, and only $25 \%$ are from deceased donors. Turkey had among the highest rates of organ donation by live donors of any country in the world in 2018, with a rate of 52 ppm (7). Nevertheless, waiting lists for organ transplants are long, and the demand far exceeds supply. The number of deceased organ donors would have to increase in order to meet the demand. In individuals with end-stage organ failure which requires supportive treatments such as hemodialysis, organ transplantation reduces the cost to the healthcare system and provides a better quality of life for the patient.

There are many reasons for low rates of deceased organ donation. One survey found that barriers included a limited understanding of the patient's prognosis and limited emotional readiness to donation on the part of family members, but staff also identified several facilitators

Table 3. Hospitalization time and diagnosis

\begin{tabular}{|l|l|l|l|l|}
\hline $\begin{array}{l}\text { Groups } \\
\text { Diagnose time after hospitalization (days) }\end{array}$ & N & Mean & Standard deviation & Standard error mean \\
\hline $\begin{array}{l}\text { Non-donor } \\
\text { Donor }\end{array}$ & 54 & 5.5185 & 3.01406 & 0.41016 \\
\hline $\begin{array}{l}\text { Total hospitalization time (days) } \\
\text { Non-donor }\end{array}$ & 6 & 2.0000 & 1.09545 & 0.44721 \\
\hline $\begin{array}{l}\text { Donor } \\
\text { Duration of survival after diagnosis (days) }\end{array}$ & 6 & 7.6667 & 3.59244 & 0.48887 \\
\hline Non-donor & & 3.0000 & 1.67332 & 0.68313 \\
\hline Donor & 54 & 2.4630 & 2.91038 & 0.000 \\
\hline
\end{tabular}


of organ donation (10). Members of the general population do not understand that $\mathrm{BD}$ is irreversible and expect that individuals who are $\mathrm{BD}$ will recover completely because cardiac death has not occurred. Concerns about killing the patient to enable the patient's organs to be donated may be the reason for family veto.

Secondly, a delay in the diagnosis of BD may be as much of a contributor as family refusals. The interval between clinical suspicion of BD and confirmation of the diagnosis has varied widely across studies. In our study, it took a mean of 5.1 days to confirm the diagnosis of BD. This is a relatively short period compared to some other studies. A two-center study found that the interval between suspicion of BD and diagnosis was 6.7 days at the one center and 1.7 days at the other center (11). Tsai et al. (12) reported that this period was 6.6 days. Two other studies reported that the time taken from suspicion of BD to diagnosis was 5.9 days and 8.2 days, respectively $(6,9)$.

The interval between confirmation of diagnosis of BD and terminating respiratory and circulatory support, known as somatic survival, has also varied across studies. In our study, the mean somatic survival was 2.5 days. In one study, somatic survival has been reported to be approximately 4 days (13) Özmert et al. (9) found that somatic survival was 6.9 days among non-donors and another study found that somatic survival was 6.8 days in patients $<18$ years, and 2.5 days in patients $>18$ years (4).

According to the world standards, at least one case of BD needs to be reported for each ventilatory ICU bed per year. Although there are $>2,500$ ventilatory ICU beds in Turkey, there are an average of only 500 BDs per year (14). The diagnosis of BD may be delayed if routine neurological examination is delayed while patients are being treated for other systemic disorders, and by a lack of communication with transplant coordinators (15). A review of cases of BD that occurred in emergency departments found that up to $84 \%$ of cases were not diagnosed due to failure of the diagnostic process (16).

In Turkey, organs of deceased patients cannot be used for transplantation without the consent of relatives, even if the deceased patient has an organ transplant volunteer card or has expressed a willingness to be an organ and tissue donor while healthy, or in a written will. Legal reforms are needed to prevent relatives from vetoing organ donation to which deceased patients have consented. In countries such as Belgium, Spain, and France, where an "opting out" or "presumed consent" model is used, there are a high number of cadaveric donors. According to this model, organs can be used for transplantation after death unless the individual has expressed an objection (17). Several studies have reported an association between assumed consent and high organ donation rates $(18,19)$.

Although there have been many studies on organ donation after BD, the relationship between the time taken to confirm $\mathrm{BD}$ and the organ donation rate has not been studied. Our study differs from other studies in this regard. It was found that the time to confirm the diagnosis of BD was significantly shorter in donors than in non-donors. Early diagnosis of BD was associated with an increased rate of family approval for organ donation. Long hospitalization may lead relatives to veto organ donation because a longer stay provides greater hope of recovery and because of a lack of understanding of the situation by family members.
This study has some limitations. Firstly, we had no qualitative data to provide insight into the reasons for family members' reluctance to consent to organ donation by brain-dead patients. Similarly, we had insufficient information on the reasons why family members provided consent to organ donation among the family members who did consent. These reasons could be clarified by asking family members to answer a questionnaire about reasons for consenting to, or vetoing, deceased organ donation after informing them of the brain dead of their family member. This would clarify the ethical, religious, and sociological reasons for consenting to, or vetoing, organ donation by their deceased relative. Secondly; the study does not provide insight into quantifiable markers for early detection or diagnosis of $\mathrm{BD}$, transplantation coordination, or changes to the legal framework. A prospective study should be conducted to gain a better understanding of these issues. Thirdly, it is unclear whether the results of this study are applicable to other hospitals, so a multicenter study is required.

\section{Conclusion}

In conclusion, in order to overcome the shortage of organ donations, a system should be established that protects donors and recipients. Early identification of potential donors, well-organized transplantation coordination systems, legal improvements, and measures to alter the perception of $\mathrm{BD}$ among the general public may increase deceased organ donation.

Ethics Committee Approval: The study was approved by İstanbul University Clinical Research Ethics Council (decision no: 2013/1748), we conducted a retrospective review of 60 patients diagnosed as brain dead in our hospital between January 1, 2004 and January 1, 2013

Informed Consent: Retrospective study.

Peer-review: Externally and internally peer-reviewed.

Author Contributions: Surgical and Medical Practices - T.Y, P.E.Ö.; Concept - T.Y, P.E.Ö.; Design - T.Y, P.E.Ö.; Data Collection and/or Processing - T.Y, P.E.Ö.; Analysis and/or Interpretation - T.Y, P.E.Ö.; Literature Search T.Y, P.E.Ö.; Writing Manuscript - T.Y, P.E.Ö.

Conflict of Interest: No conflict of interest was declared by the authors.

Financial Disclosure: The authors declared that this study received no financial support

\section{References}

1. Pestana AL, dos Santos JL, Erdmann RH, da Silva EL, Erdmann AL. Lean thinking and brain-dead patient assistance in the organ donation process. Re Rev Esc Enferm USP 2013; 47: 258-64.

2. 2. IÜ/İzleme ve Değerlendirme Birimi, Sayılarla TTDis. Nakil Bekleyen Hasta Sayıları October 2019;10 (cited: 01/01/2019) Available from: URL: https:// organ.saglik.gov.tr/ContentView.aspx?q=1

3. Eira CSLD, Barros MIT, Albuquerque AMP. Organ donation: the reality of an intensive care unit in Portugal. Rev Bras Ter Intensiva 2018; 30: 201-7.

4. Karasu D, Yılmaz C, Karaduman I, Çınar YS, Buyukkoyuncu Pekel N Retrospective analysis of brain death cases. Yoğun Bakım Journal 2015; 6: 23-6

5. Battal M, Horoz A, Karatepe 0, Çitgez, B. Beyin ölümü tespitinde araștırma hastanesi deneyimi. Șișli Etfal Hastanesi Tıp Bülteni 2013; 47: 59-62. 
6. Mutlu, NM, Peker TT, Acar S, Koca B, Soyal ÖB, Titiz AP, et al. Brain Deaths and Donors in an Education and Research Hospital." Transplantation proceedings. Elsevier 2019; 51: 2176-9.

7. International Registry in Organ Donation and Transplantation. Turkey Deceased Organ Donor Evolution June 2019 (cited :01/07/2019) Available from: URL: http://www.irodat.org/?p=database\&c=TR\#data

8. Kıraklı C, Uçar ZZ, Anıl AB, Özbek İ. The effect of shortening the definitive diagnosis time on the organ donation rates in the intensive care unit, Yoğun Bakım Journal 2011; 1: 8-11.

9. Özmert S, Sever F, Ayar G, Yazıcı MU, Öztaş DK. Brain Death and Organ Donation in Paediatric Intensive Care Unit." Turk J Anaesthesiol Reanim 2019; 47: 55-61.

10. Oczkowski SJ, Durepos P, Centofanti J, Arsenau E, Dhanani S, Cook DJ, et al. Multidisciplinary Survey to Assess Facilitators and Barriers to Successful Organ Donation in the Intensive Care Unit. Prog Transplant 2019; 29: 179-84.

11. Gündüz RC, Sahin S, Uysal-Yazıcı M, Ayar G, Yakut HI, Akman AÖ, et al. Brain death and organ donation of children. Turk J Pediatr 2014; 56: 597.

12. Tsai E, Shemie SD, Cox PN, Furst S, McCarthy L, Hebert D. Organ donation in children: role of the pediatric intensive care unit." Pediatr Crit Care Med 2000; 1: 156-60.
13. George S, Thomas M, Ibrahim EH, Abdussalam A, Chandra P, Ali HS, et al. Somatic survival and organ donation among brain-dead patients in the state of Qatar." BMC Neurol 2016; 16: 207.

14. Tepehan S, Elmas İ. Türkiye'de Beyin Ölümü Tanısına Güven Sorunu ve Organ Bağıșına Yansımaları. Yoğun Bakım Hemșireliği Dergisi 2014, 18.1: 8-14.

15. Girlanda R. Deceased organ donation for transplantation: Challenges and opportunities. World J Transplant 2016; 6: 451-9.

16. McCallum, J, Ellis, B, Dhanani S, Stiell, IG. Solid organ donation from the emergency department-A systematic review. CJEM 2019; 21: 626-637.

17. Koçak Süren S. Organ ve doku naklinin yasal ve etik açıdan incelenmesi. Türkiye Barolar Birliği Dergisi 2007; 73: 174-95

18. 18. Rithalia A, McDaid, C, Suekarran S, Myers L, Sowden A. Impact of presumed consent for organ donation on donation rates: a systematic review. BMJ 2009; 338: a3162.

19. English V, Johnson E, Sadler BL, Sadler AM. Is an opt-out system likely to increase organ donation?. BMJ 2019; 364: 1967. 